\title{
LA RELACIÓN IDEOLÓGICA DE ALONSO DE ERCILLA CON FRANCISCO DE VITORIA Y FRAY BARTOLOMÉ DE LAS CASAS ${ }^{1}$
}

\author{
POR \\ WiLLIAM MEJíAs-LóPEZ \\ University of New Hampshire
}

\section{Francisco de Vitoria y Fray Gil González de San Nicolás}

En la España del siglo XVI fueron muy conocidas las ideas de teólogos y religiosos que influyeron en la política de la conquista de América, el derecho y las leyes internacionales. El ejemplo más representativo es Francisco de Vitoria, dominico y profesor de teología en la Universidad de Salamanca desde el 1526 hasta el 1546. Gozó de gran reputación en toda Europa y se le reconoce como el iniciador en España de los estudios sobre Santo Tomás de Aquino. ${ }^{2}$ Por sus cátedras pasaron unos 5.000 alumnos, algunos de los cuales ocuparon puestos distinguidos en América y en Europa. ${ }^{3}$

Vitoria dictó cientos de cátedras. Sin embargo, lo que le dio fama fueron sus "relecciones" leídas entre 1527-1539.4 Hubo dos que suscitaron polémicas: De Indis, (1538) y De jure belli (1539). En estos dos trabajos Vitoria comenzó la defensa apasionada de los indios americanos y las críticas contra España por la manera despiadada en que conquistaba a las Indias. ${ }^{5}$ Los principios formulados en estas relecciones se convirtieron

\footnotetext{
${ }^{1}$ Porción de este estudio se presentó como parte de una ponencia para la Mid-America Conference on Hispanic Literature, celebrada en Washington University (Saint Louis, MO, 28 de octubre de 1988). También algunas secciones se lograron exponer en el XXVIII Congreso del Instituto Internacional de Literatura Iberoamericana realizado en Brown University del 18-al 21 de junio de 1990.

${ }^{2}$ Es importante saber este dato, pues Francisco de Vitoria utiliza muchas de las ideas de Santo Tomás sobre la guerra justa. Las aplicará a los indios. Para comprender la relación entre estos dos religiosos, consúltese el trabajo de Manuel Torres López, "La doctrina de Santo Tomás de Aquino sobre la guerra justa y sus influencias en la de Francisco de Vitoria", Anales de la Facultad de Filosofia de la Universidad de Granada 1 (Granada, 1919) 6-28.

${ }^{3}$ Enrique de Gandía, Francisco de Vitoria yel Nuevo Mundo (Buenos Aires: Editorial Vasca, 1952) 88. Quizá el más conocido de todos sea el padre Domingo de Soto.

${ }^{4}$ Éstas eran conferencias pronunciadas por licenciados o catedráticos en su facultad o toda la Universidad. Trataban sobre temas palpitantes y de mucha vigencia. Beltrán de Heredia, Francisco de Vitoria (Barcelona: Editorial Labor, 1939) 71.

${ }^{5}$ Sobre Francisco de Vitoria y las Indias, véase a Rubén Vargas Ugarte, "Fray Francisco de Vitoria y el derecho a la conquista de América", Boletín del Instituto de Investigaciones Históricas, 11
} 
posteriormente en ideales que sus discípulos apoyarían con ardor. Respecto a la guerra defensiva en América, uno de los seguidores más fieles fue su discípulo Fray Gil González de San Nicolás, amigo también de Bartolomé de Las Casas. ${ }^{6}$ Después de sus estudios en Salamanca, Fray Gil viajó a Lima donde se dedicó a velar por los derechos de los indios. Esta posición hizo que Domingo de Santo Tomás, provincial de los dominicos en Perú, lo nombrara para que fuera a Chile en 1552 con el cargo de protector de indios y vicario general. ${ }^{7}$ No salió para Chile sino cinco años más tarde. La fecha de partida coincidiría con la expedición de García Hurtado de Mendoza, nombrado recientemente gobernador de la colonia por su padre y virrey del Perú Antonio Hurtado de Mendoza. No nos extrañan las influencias del dominico en el gobierno de Lima. Tal vez expliquen por qué el virrey demostró algunas delicadezas al estipular las prerrogativas de que gozaría mientras se lograba la pacificación de los araucanos: "derecho para hablar, para hacer observaciones, para pedir ser oído y respetado". ${ }^{8}$ Hasta le revistió de autoridad para opinar sobre los procedimientos a emplearse en la cristianización de estos rebeldes.

Una vez en Chile, no demoró en extender las enseñanzas de su maestro Vitoria al campo de batalla. Si por un lado acentuaba el respeto a la guerra defensiva, por el otro enaltecía la preservación de la justicia y el bienestar de los nativos. Dicha conducta desembocó en desavenencias entre él y García Hurtado de Mendoza debido a que este gobernante ignoraba la pacificación libre de violencia. Pero esto no inhibió al dominico de utilizar el púlpito para predicar a los soldados que les aguardaría el infierno si seguían las órdenes de su jefe. Góngora Marmolejo, cronista del período, menciona que para Fray Gil las guerras y levantamientos de los indios eran justificables, pues respondían a los abusos de los españoles. Advierte que las palabras del dominico "eran dichas con tanta fuerza, que hacían grande impresión en los ánimos de los capitanes y soldados". ${ }^{9}$ En Chile las protestas de Fray Gil no sólo provocaban discordias, sino que estorbaban los planes de don García. Fue por esto que el gobernador decidió trasladarlo a Lima. Curiosamente, en

(Buenos Aires, 1930) 29-44. José Miranda, Vitoria y los intereses de la conquista de América (México: Colegio de México, 1947); Teodoro Andrés Marcos, Vitoria y Carlos Ven la soberanía de Hispano-América (Salamanca: n. e., 1946). Enrique de Gandía, Francisco de Vitoria y el Nuevo Mundo (Buenos Aires: Editorial Vasca, 1952). También a Camilo Barcía Trelles, Interpretación del hecho americano por la España universitaria del siglo XVI(Montevideo: n. e., 1949); Venancio Carro, La teología y los teólogos juristas españoles ante la conquista de América, 2 volúmenes (Madrid: Talleres Gráficos Marsiega, 1944). Del mismo autor "El indio y sus derechos y deberes, según Francisco de Vitoria", Revista de Indias, VII/24 (Madrid, abril-junio, 1946) 253-269. De Alonso García Gallo, "La posición de Francisco de Vitoria ante el problema indiano. Una nueva interpretación", Revista del Instituto de Historia del Derecho, 2 (Buenos Aires, 1950) 47-66.

${ }^{6}$ Sobre esta amistad véase a Marcel Bataillon, Estudio sobre Bartolomé de Las Casas (Barcelona: Ediciones Península, 1976) 70, 71, 88 y 89; Manuel Giménez Fernández, "Las Casas y el Perú", Documenta, II/1 (Lima, 1949-1950) 343-377. Véase nota 78.

${ }^{7}$ Eugene Korth, Spanish Policy in Chile (Stanford: Stanford University Press, 1968) 40.

${ }^{8}$ Crescente Errázuriz, Historia de Chile: Garcia Hurtado de Mendoza, II (Santiago de Chile: Universidad de Chile, 1914) 96.

${ }^{9}$ Góngora Marmolejo, Historia de Chile desde su descubrimiento hasta el año de1575, Biblioteca de Autores Españoles, 131 (Madrid: Atlas, 1960) 143. 
su viaje de vuelta al virreinato, Fray Gil fue compañero de tripulación de Ercilla, quien abandonaba Chile luego de sufrir serios percances con el gobernador a raíz de su disputa con el soldado Pineda. Puesto que las injusticias en las guerras contra los indios constituían las conversaciones preferidas del dominico, el que ambos viajaran juntos nos induce a pensar que discutieron la problemática del indio en Chile y el desarrollo de las guerras. ${ }^{10}$ Contribuiría también a sus charlas la duración del viaje. Según José Toribio Medina, el trayecto por mar de Concepción, Chile al puerto del Callao, Lima tardaba aproximadamente unos 58 días. ${ }^{11}$ Por otra parte, si apreciamos el espíritu crítico de Ercilla, hay que asentir en que tuvo que haber escuchado en Chile las protestas del fraile contra la guerra ofensiva y contra García Hurtado de Mendoza. Lo que realmente escuchó es un misterio. No obstante, esto no impide que tracemos algunas huellas que Vitoria y Las Casas probablemente dejaron en el poeta a través de Fray Gil.

\section{El DERECHO DE LOS INDÍGENAS A SUS PROPIEDADES}

Para Vitoria y Las Casas, igual que para Fray Gil, los indígenas eran propietarios absolutos de sus tierras y posesiones. Claro que estas ideas tenían pocos seguidores. Desde siglos antes quedaron bosquejados los criterios sobre posesiones de tierras y propiedades por parte de algunos grupos (mayormente gentiles, judíos y herejes) cuyas creencias religiosas antagonizaban con las del Vaticano. Las mismas se incorporaron como leyes. Con la conquista y el descubrimiento de indios en América vuelven a replantearse cuestiones semejantes. Así, ya temprano en el siglo XVI, el jurista Juan López de Palacios Rubios, en su requerimiento de 1512, redactado a petición del rey Fernando, el Católico, había revestido a los españoles de vasto poder para desapropiar a los americanos de sus bienes de éstos ser desleales a la autoridad de los reyes españoles y a la de la Iglesia Católica. Este desalojo se haría mediante una guerra justa. ${ }^{12}$

Para sorpresa de los que aplaudían estas recomendaciones, el Papa Pablo III planteó en la bula Sublimis Deus de 1535 (en alusión a los amerindios) que la distancia ideológica de los que se negaban a abrazar la doctrina cristiana no era excusa para adueñarse de una

\footnotetext{
${ }^{10}$ Cruchaga Ossa, "Ercilla y el derecho internacional", Homenaje de la Universidad de Chile a su ex Rector don Domingo Amunátegui Solar en el 75o aniversario de su nacimiento, I (Santiago de Chile: Imprenta Universitaria, 1935) 162.

${ }^{11}$ Véase José Toribio Medina, Vida de Ercilla (Santiago de Chile: Imprenta Elzeviriana, 1917) 96, nota 229. Se cree también que Fray Gil y Ercilla viajaron juntos desde Valparaíso y no desde Concepción. Lo cierto es que Concepción era el puerto principal en ese entonces. De todas maneras, no había mucha diferencia en el tiempo que demoraban ambas rutas.

${ }^{12}$ Las huellas de este documento parecen encontrarse en la bula Inter Cetera, del Papa Alejandro VI. En esta bula de 1493, el Pontífice les concedía a los Reyes Católicos la legítima dominación de las tierras americanas y exigía que los monarcas miraran el bien espiritual de los indígenas. Esto reforzaba los vínculos del Vaticano con el carácter espiritual de la conquista de América. Este texto sería clave para la virtual expropiación a la cual estaban sujetos los indígenas de no aceptar el poder real ni la religión católica. Claro que aquéllos que los favorecían corrían la misma suerte de los que oponían resistencia. Véase Manzano Manzano, La incorporación de las Indias a la corona de Castilla (Madrid: Edición de Cultura Hispánica, 1948) 45-47.
} 
partícula de estas haciendas. ${ }^{13}$ Dos años después esta política española ganó el repudio de Vitoria, que en De Indis abogó por el derecho de los nativos al disfrute de sus propiedades. Los concebía pública y privadamente dueños de sus pertenencias: señores en derecho. ${ }^{14}$ Sus casas y tierras no podrían quitárseles sin causa justa. No conforme con esto, afirmó que las riquezas americanas debían permanecer en manos de los americanos. De los conquistadores haber realizado desapropiaciones debería averiguarse si se procedió con justicia o injuria. ${ }^{15}$ Hasta recriminó que por motivaciones ideológico-religiosas se despojara a los aborígenes de sus bienes. Reconocía que España gozaba de determinados derechos, pero según determinado orden y justicia. Para Las Casas, estas expropiaciones no alentaban la paz, sino la confrontación.

Fray Gil, de actitudes más radicales, defendía el derecho de los araucanos a emprender una guerra defensiva y justa para proteger su libertad, casas y haciendas de la rapacidad de los conquistadores. Góngora Marmolejo, quien suponemos estuvo al tanto de las protestas del religioso, clarifica este hecho: "Juntósele a Villagra para no acertar a hacer la guerra, que Fray Gil, en las oraciones que hacía a los soldados, les decía se iban al infierno si mataban indios, y que estaban obligados a pagar todo el daño que hiciesen y todo lo que comiesen, porque los indios defendían causa justa, que es su libertad, casas y haciendas". ${ }^{16}$ Es curioso que Ercilla recurra deliberadamente a las mismas palabras para expresar los temores de los indígenas de perder estos privilegios. En varias estrofas destaca el valor que tiene para ellos la libertad y la hacienda. Nada sorprende que confie su protección al cacique Tunconabala, personaje de La Araucana, que inculca en algunos compañeros conciencia sobre los peligros que se avecinarían de resultar victoriosos los conquistadores:

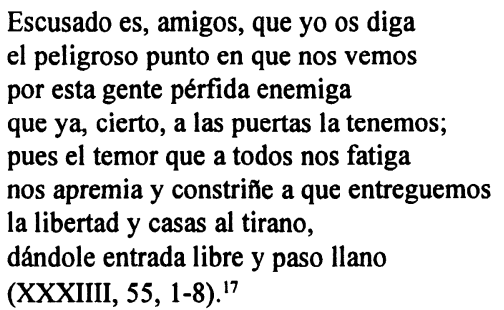

${ }^{13}$ Véase Mariano Cuevas, Documentos inéditos del siglo XVI para la historia de México (México: Museo Nacional de Arqueología, Historia y Etnología, 1914) 26. Véase también Alberto de la Hera, "El derecho de los indios a la libertad y a la fe. La bula Sublimis Deus y los problemas indianos que la motivaron", Anuario de Historia del Derecho Español, XXVI (Madrid, 1956) 89181 y Lewis Hanke, "Pope Paul III and the American Indians", Harvard Theological Review, XXX (Cambridge, 1937) 65-102.

${ }^{14}$ Francisco de Vitoria, Las relecciones 'De Indis' y 'De Iure Belli', Javier Malagón Barceló, editor (Washington, DC: Unión Panamericana, 1963) 175.

${ }^{15}$ Francisco de Vitoria, 173.

${ }^{16}$ Góngora Marmolejo, Historia de Chile ..., 143.

${ }^{17}$ Para este estudio de La Araucana hemos manejado la edición de Marcos Morínigo e Isaías Lerner, 2 volúmenes (Madrid: Castalia, 1979). 
No fueron menos auguradoras las advertencias de Tucapelo, para quien la libertad y hacienda formaban derechos dependientes y recíprocos:
Y si algún miserable no concede lo que tan justamente le es pedido, por enemigo de la patria quede y del militar orden escluido: que ya por nuestra parte no se puede venir a ningún medio ni partido sin dejar de perder, pues la contienda es sobre nuestra libertad y hacienda (XXIX, 13, 1-8).

Ercilla se solidariza con las posiciones indígenas hacia España y la conquista. Para los indios el control español era sinónimo de desarraigo. Sus discursos atestiguan la usurpación de sus dominios y su libertad. Es posible que Ercilla haya seleccionado a dos personajes araucanos que no pertenecían a la jerarquía superior para establecer que este problema de la conquista concernía a todos. El poeta no opina, sino, más bien, procura que sean los indios los que ofrezcan testimonios de los daños españoles. De esta manera encubría sus críticas personales directas. Sea cual fuese el motivo, ${ }^{18}$ esta queja coincide con la de los otros religiosos. ${ }^{19}$

\section{INTELIGENCIA Y GOBIERNO DE LOS ARAUCANOS}

Cuando estudiamos las páginas de La Araucana en las cuales Ercilla valora la inteligencia y capacidad de gobierno de los araucanos, sobresalen de inmediato sus coincidencias con Vitoria y Las Casas. ${ }^{20}$ Hasta donde sabemos, Fray Gil no se expresó sobre el tema. Es menester insistir en que estas opiniones no eran las predominantes en el siglo XVI. Palacios Rubios y Ginés de Sepúlveda señalaban a los indígenas como seres incivilizados; incapaces de gobernarse con leyes y prudencia. Creía Palacios Rubios que esta limitación ampliaba la brecha entre los hombres más y menos inteligentes. Los indígenas no cabían dentro del primer grupo; inclusive, su ausencia de razón hacía obligatoria su sujeción a los criterios de los más aptos. Sobre todo, es curiosa su afirmación de que esta ineficiencia les vedaba de tener gobiemos comparables a los de los pueblos civilizados.

\footnotetext{
${ }^{18}$ Sospechamos que este interés de Ercilla en permitirles a los araucanos hacer las críticas más fuertes contra España podrían explicarse desde una perspectiva legal. El poeta defiende el derecho de los indígenas a expresar opiniones libremente. Véase mi artículo titulado "Alonso de Ercilla y los problemas de los indios chilenos: algunas prerrogativas legales presentes en La Araucana", Bulletin of Hispanic Studies, Spain and Portugal. The Discoveries and the Colonies, 1492-1898 LXIX/1 (University of Liverpool, 1992) 1-10.

${ }^{19}$ Para una idea general del derecho privado en la época colonial, véase José María Ots Capdequi, $E l$ Estado español en las Indias (México: El Colegio de México, 1941). Las páginas 113-145 están dedicadas al derecho de propiedad.

${ }^{20}$ Hasta donde sabemos, Fray Gil no se expresó sobre el tema.
} 
En su tratado De las islas del mar Océano (1512-1514) toma de referencia la doctrina de Aristóteles, ${ }^{21}$ Santo Tomás de Aquino ${ }^{22}$ y Egidio Romano ${ }^{23}$ para elaborar sus juicios sobre la servidumbre natural, y cómo ésta se podía extender a los indios. ${ }^{24}$ Muy cerca ideológicamente de Palacios Rubios, Sepúlveda buscó también amparo en el pensamiento aristotélico. Propuso que de aspirar los aborígenes a desligarse de imperios o gobiernos más adelantados, quedaría justificada una guerra justa contra ellos. ${ }^{25}$

Lamentablemente, muchos de los prejuicios contra los indígenas por parte de los conquistadores que viajaban a América coincidieron notablemente con los de Palacios Rubios y de Sepúlveda. Aunque parece indudable que la mayor parte desconocía a estos dos pensadores, la creencia de que los indios eran inferiores prevalecía entre los que venían a explorar. Para el comendador Bobadilla (1500-1502) de la Española eran bestias irracionales. ${ }^{26}$ Igual pensaban Francisco de Garay, Juan Ponce de León y Pedro García de Carrión: ${ }^{27}$ Antonio de Villasante los consideraba incapaces de amoldarse a patrones de conducta apropiados. En la peor de las circunstancias ni siquiera rebasaban al más rudo de los españoles. ${ }^{28}$ Para Lucas Vázquez de Ayllón se asemejaban a las bestias libres. ${ }^{29}$ Entre algunos cronistas de esa época, los indios tampoco fueron bien vistos. Fray Vicente Palatino de Curzola, en 1559, acude al apelativo "bestias fieras" para incluir a aquéllos con los cuales había tratado Pizarro. ${ }^{30}$ Admirador de Sepúlveda, Francisco López de Gómara

${ }^{21}$ La Política (Madrid: Espasa-Calpe, 1974). Véanse especialmente los libros I y II.

${ }_{22}$ De Regimine Principum ad regen Cypri et De regimine Judaeorum ad ducissam Brabantiae (Taurini: Marietti, 1971). Véase el libro II, capítulo X.

${ }^{23}$ De Regimine Principum existe una edición en español titulada Glosa castellana al "Regimiento de príncipes", edición y estudio preliminar de Juan Beneyto Pérez (Madrid: Instituto de Estudios Políticos,1947). Véase el libro II, parte III, capítulo VIII. El nombre Egidio Romano aparece también como Egidio Colonna. Ambos aluden a la misma persona.

${ }^{24}$ Juan López de Palacios Rubios, De las islas del mar Océano, introducción de Silvio Zavala (México: Fondo de Cultura Económica, 1954).

${ }^{25}$ Silvio Zavala, Servidumbre natural y libertad cristiana según tratadistas españoles de los siglos XVI y XVII (Buenos Aires: Peuser, 1944) 45. En Tratado sobre las justas causas de la guerra contra los indios, Sepúlveda plantea algunas de estas ideas. Señala el religioso: "Téngase, pues, por cierto é inconcluso, puesto que lo afirman sapientísimos autores, que es justo y natural que los hombres prudentes, probos y humanos dominen sobre los que no lo son, y esta causa tuvieron los romanos para establecer su legítimo y justo imperio sobre muchas naciones", véase Tratado ... (México: Fondo de Cultura Económica, 1941) 99-101.

${ }^{26}$ Véase Fray Luis Gómez Canedo, “¿Hombres o bestias?”, Estudios de Historia Novohispana, I (México, 1966) 31.

${ }^{27}$ Fray Luis Gómez Canedo, 32.

${ }^{28}$ Véase Lewis Hanke, Uno es todo el género humano: estudio acerca de la querella que sobre la capacidad intelectual y religiosa de los indios americanos sostuvieron en 1550 Bartolomé de Las Casas y Juan Ginés de Sepúlveda (México: Gobierno Institucional en España, 1974) 24.

${ }^{29}$ Lewis Hanke, Uno es todo el género ..., 24.

${ }^{30}$ Lewis Hanke y Agustín Millares Carlo, "Tratado del derecho y justicia de la guerra que tienen los reyes de España contra las naciones de la India Occidental", Cuerpo de documentos del siglo XVI sobre los derechos de España en las Indias y las Filipinas (México: Fondo de Cultura Económica, 1943), 25. 
equiparaba a los indios con asnos estúpidos. ${ }^{31}$ Fernández de Oviedo, con todo el desprecio que sentía hacia esta raza, asumió, sin embargo, juicios positivos y negativos. ${ }^{32}$ Quizá uno de los más virulentos ataques contra los indígenas procede de Pedro Mártir de Anglería, quien, si bien no viajó a América, inserta en sus Décadas una carta posiblemente escrita por el dominico Juan Pedro de Córdoba dirigida al Consejo de Indias para ilustrar los puntos flojos de los americanos:

Los indios - se afirma en la misma - comen carne humana. Son sodomitas, peores que cualquiera otra nación. No existe la justicia entre ellos. Están completamente desnudos. No respetan ni el amor ni la virginidad. Son brutos e imbéciles. Sólo se atienen a la verdad si les conviene. Son inconstantes. Son absolutamente incapaces de imaginarse lo que significa la previsora precaución. Son muy desagradecidos y veleidosos. Se jactan de la embriaguez que adquieren con la bebidas que preparan con determinadas hierbas, frutas y granos, semejantes a nuestra cerveza o sidra ... Son brutales, desobedientes, traicioneros, crueles, vengativos, implacables, ladrones; carecen de buena fe. Comen piojos, arañas y gusanos, sin cocerlos. No conocen ningún oficio. Si se les explica la religión cristiana, dicen que ésta cuadra a los españoles, pero no a ellos. Se afeitan la barba. Son despiadados con sus enfermos. Si alguno cae enfermo, lo llevan a las montañas para que perezca allí. Cuando más viejos, más malvados. Son verdaderas fieras y feroces. Jamás Dios hizo raza alguna tan llena de vicios y bestialidades y sin el menor rastro de bondad ni cultura. ${ }^{33}$

Sin embargo, Vitoria y Las Casas ignoraron estos prejuicios. Sobran ejemplos en la obra de Vitoria que depositan su confianza en los indios. En particular, elogia su capacidad de razón:

Porque en realidad no son amentes, sino que a su modo tienen el uso de razón. Y es manifiesto. Porque tienen establecidas cosas con cierto orden, puesto que tienen determinados matrimonios, magistrados, señores, leyes, artesanos, todo lo cual requiere uso de razón. ${ }^{34}$

\footnotetext{
${ }^{31}$ Hanke, Uno es todo el género ..., 24.

${ }^{32}$ Véase Gómez Canedo demuestra que la visión del indígena de Fernández de Oviedo ha sido mal interpretada. Comenta que si bien en un extremo el cronista juzgaba a ciertas clases de aborígenes como "perezosos, glotones, lascivos, traidores y crueles", éste reconoce asimismo las buenas cualidades, habilidad y nobleza de otros. Y no oculta los abusos de conquistadores y colonos (nota 3, páginas 30-31). Con todo, Las Casas atacó duramente las opiniones que Oviedo incluyó en su Historia general y natural de las Indias, islas y tierra firme del mar Océano contra los indios. Véase Las Casas, Historia de las Indias, III, libro III, capítulo CXLII (México: Fondo de Cultura Económica, 1951) 320-336.

${ }^{33}$ Pedro Mártir de Anglería, De orbe novo, citado por Joseph Hoffner, La ética colonial española del siglo de oro: cristianismo y dignidad humana (Madrid: Ediciones Cultura Hispánica, 1957) 136-137.

${ }^{34}$ Francisco de Vitoria, De Indis, citado por Lewis Hanke, El prejuicio racial en el Nuevo Mundo (México: SepSetentas, 1974), 52.
} 
Sobre la aptitud racional de los aborígenes, Las Casas escribió extensamente. En Historia de las Indias los califica como hombres con entendimiento. ${ }^{35}$ Ahora bien, tiene dos crónicas en las que examina minuciosamente su inteligencia y sensatez: De Unico vocationis modo ${ }^{36}$ e Historia apologética sumaria. En este último título acumula evidencia histórica comparando las civilizaciones americanas (mayas, incas, aztecas, entre otras) con las de los pueblos antiguos (griegos, romanos, egipcios, etc.) para comprobar que las "indianas gentes son intelectivas, ingeniosas, racionales y de buena capacidad". ${ }^{37}$ En sus

${ }^{35}$ Libro III, capítulo CXLV, 330. Véase supra, nota 32.

${ }^{36}$ Trabajo escrito originalmente en latín, traducido al español por Atenógenes Santamaría. Véase Del único modo de atraer a todos los indios a la verdadera religión, edición de Agustín Millares Carlo e introducción de Lewis Hanke (México: Fondo de Cultura Económica, 1942).

${ }^{37}$ Bartolomé de Las Casas, Apologética historia sumaria, 2 volúmenes, Edmundo O'Gorman editor (México: Universidad Nacional Autónoma de México, 1967) 171. En esta crónica, Las Casas estudia a los indios desde el punto de vista de la antropología geográfica. Examina las condiciones de la naturaleza para explicar los rasgos que éstos poseen. Los capítulos XL-XLV destacan la prudencia numástica, económica y política de los aborígenes de acuerdo al esquema aristotélico (Volumen I, páginas 211-241). Admira la grandeza de la civilización azteca, maya, inca, entre otras. Y compara estas civilizaciones con las de la antigúedad clásica (XLIX-LVIII). Establece, usando los criterios aristotélicos, las razones por las cuales la sociedad indígena es perfecta. Aunque reconoce que uno de los defectos de esta raza fue la idolatría, esta debilidad no sólo fue típica de los indios, sino también de los pueblos griegos y egipcios (Libro III, capítulo LXXV). Insiste en la insensibilidad de los griegos en tener por dioses a hombres infames e ignominiosos como fue Baco, las artes adivinadoras de esta civilización, oráculos (el de Delfos, Apolo, etc.), magia, hechizos, etc. Estos mismos defectos son compartidos por otros pueblos (Libro III, capítulo LXXVIII-CII). Compara la idolatría de los antiguos habitantes del Viejo Mundo con la del Nuevo Mundo (CV-CXXVII) para clarificar que los indios o "aquestas gentes, o la mayor parte dellas, tuvieron muchas menos fealdades que otras afamadas y políticas naciones de la antigüedad, y con menos heces de errores en su idolatría" (Libro III, capítulo CXXVII, 633). Continúa apuntando que en "la elección de los dioses tuvieron más razón y discreción y honestidad que los de las más de todas cuantas naciones idólatras hobo (sic), bárbaros, griegos y romanos, a todos cuantos hicieron en esto ventaja, y por consiguiente mostraron ser más que todas racionales" (663). Aun en los edificios de los templos de los pueblos de las Indias "mostraron ser gentes más que otras muchas (sic) racionales, y les hicieron mucha ventaja" (Volumen I, libro III, CXXXII, 688). Respecto a los sacrificios humanos, los griegos y latinos hicieron algunos para honrar sus dioses (Volumen II, libro III, capítulo CLXI). Así esclarece que por sacrificar humanos los indios no son irracionales, pues los sacrificios son antiguos y universales, cometidos en casi todas las naciones del mundo (Volumen II, libro III, capítulo CLXICLXXXI). En Historia de Indias, Las Casas resume los logros de Apología, De unico vocationis modo y Apologética historia en clarificar el entendimiento y policía de los indios. Véase Libro III, capitulo CLII. Comenta Las Casas, refiriéndose a estas tres obras: “... donde pongo muy en particular y a la larga las costumbres y vida y religión y policía y gobernación que todas estas naciones tenían, unas más y otras menos, y todas, empero, que mostraron ser hombres razonables y no siervos por natura, como el obispo dijo. Dejadas algunas pocas aún no habían llegado a la perfección de ordenada policía, como antiguamente todas las del mundo a los principios de las poblaciones de las tierras estuvieron, pero no por eso carecen aquéllas de buena razón para fácilmente ser reducidas a toda orden y conversación y vida doméstica y política" (351). 
diatribas contra los testimonios de Sepúlveda en Valladolid reduce las dimensiones del concepto "bárbaro" y esclarece las incongruencias de este atributo cuando pretende aplicarse a los indígenas. Aunque admite que algunos de éstos aparentan serlo, arguye que no lo son desde el punto de vista estricto. Sólo caben enmarcarse en la categoría de barbarie a los ignorantes de Dios. ${ }^{38}$

Esta distinción última de Las Casas define mejor su visión de los indígenas. ${ }^{39}$ Ercilla confiere al término el mismo sentido. Según él, los araucanos son bárbaros, no por crueles, que no lo eran más que los españoles, sino por faltarles el conocimiento de Dios. Contiene La Araucana una estrofa que facilita la apreciación de manera mediante la cual el poeta se restringe a la significación religiosa de "bárbaro". Notamos que en una ocasión cuando Ercilla alude a los conquistadores los adjetiva de cristianos; luego no demora en adjudicar el adjetivo bárbaros a los aborígenes. En esta antítesis entre europeos y americanos es posible ver la connotación anti-cristiana del concepto:

Como toros que van a salir lidiados,
cuando aquellos que cerca los desean,
con silbos y rumor de los tablados
seguros del peligro los torean
y en su daño los hierros amolados
sin miedo amenazándolos blandean,
así la gente bárbara araucana
del muro amenazaba a la cristiana $(\mathrm{XI}, 58,1-8){ }^{40}$

\footnotetext{
${ }^{38}$ Hay, pues, según Las Casas, otras clases de bárbaros. La segunda categoría está formada por los secundum quid. De acuerdo al dominico, este grupo "por la diferencia del idioma, no entiende a otro que con él habla". Alude a la Biblia para apoyar sus afirmaciones. Señala: "Así San Pablo (Corintios, 12) dice: Si desconozco el valor de las palabras seré bárbaro". En este mismo sentido, San Juan Crisóstomo llama a los Reyes Magos bárbaros. Las Casas explica el asunto con notable acierto: "Una estrella llamó desde su lugar de origen a los Magos y estos hombres bárbaros desde lejos emprendieron el trabajo de peregrinación". Véase Apología de Juan Inés de Sepúlveda contra Fray Bartolomé de Las Casas y de Fray Bartolomé de Las Casas contra Juan Ginés de Sepúlveda, Angel Losada editor (Madrid: Editorial Nacional, 1975) 126. En este apartado lo hace con acepciones diferentes: los que constituyen el grupo secundum quid y los que estrictamente englosan la tercera categoría (Apologia, 127). Respecto a este grupo, el sevillano es bastante explícito: "tomando este término en sentido propio y estricto, es la de aquellos hombres que, por impío y pésimo instinto, o por las malas condiciones de la religión que habitan, son crueles, no se gobiernan ni con las leyes ni con el derecho ..." (Apología, 128). No se olvida de incluir otras clases de bárbaros existentes: los que son bárbaros desde el punto de vista impropio. Éste es todo hombre cruel, inhumano, fiero y violento, alejado de la razón humana por el impulso de la ira o de la naturaleza. Añade que también "la Sagrada Escritura hace mención de tales bárbaros. Así, cuando el cruel y feroz tirano Nicanor quiso entablar batalla con Judas Macabeo en Samaria en el día sábado, los judíos que junto a él estaban le dijeron: 'No obres tan feroz y bárbaramente'" (Apología, 125).

${ }^{39}$ Debemos mencionar que en la Edad Media bárbaro también era sinónimo de pagano; es decir, de gentil. Véase Joseph Höffner, 61.

${ }^{40} \mathrm{El}$ subrayado es nuestro.
} 
La ignorancia religiosa no les restaba a los naturales las facultades para dilucidar sus propios asuntos. Al no estigmatizarlos de bárbaros por crueles o ineptos, Ercilla se resiste a reconocer la superioridad de los españoles. En esto estriba uno de los aciertos de $L a$ Araucana, pues implícita en esta defensa subyacía la confianza en la administración política de los indígenas. El peligro de que se pasara por alto esta capacidad preocupaba a Ercilla. Sabía que mediante la ejecución de los caciques, los españoles se disponían a quebrantar la unión del Arauco; por ende, su política o gobierno. Naturalmente, la persecución de estos jefes orientaba las conquistas. Hay ejemplos convincentes en el poema:

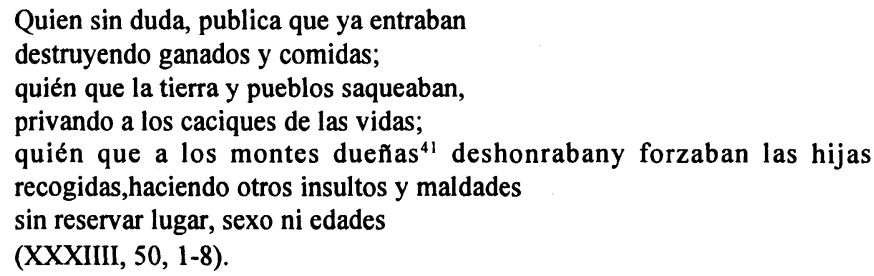

Con razón, incluyendo a Galbarino en estas muertes, Ercilla continúa más tarde subrayando la ejecución de caciques:

Yo, que estaba a par dél, considerando
el propóposito firme y osadía,
me opuse contra algunos, procurando
dar la vida a quien ya la borrecía;
pero al fin los ministros, porfiando
que a la salud de todos convenía,
forzado me aparté y él fue llevado
a ser con los caciques justiciado
(XXVI, 29, 1-8).

Galbarino concientiza a los toquis ${ }^{42}$ de la amenaza que se ciñe contra ellos y el Arauco. Al ser hecho prisionero en la batalla de Millarapué y poco después conducido a la horca, Ercilla califica su muerte de "insulto y castigo injusto" (XXVI, 30, 6). Luego, en conmovedoras estrofas, al describir el final trágico de Caupolicán, el poeta se riñe por haberse encontrado ausente y no haber podido evitar la ejecución del valiente guerrero, pese a las recriminaciones de Fresia que lo tildan de cobarde. Es innegable que estas protestas implican el reclamo de reformas políticas. Por eso reaccionaba, poniendo en boca de Galbarino las justificaciones para que no se trastornara la monarquía araucana. Era patente que los caciques daban cuerpo a este sistema:

¡Oh gentes fementidas, detestables, indignas de la gloria deste día!

\footnotetext{
${ }^{41}$ Según Morínigo, éstas eran las mujeres principales.

${ }^{42}$ Caciques o jefes araucanos.
} 
Hartad vuestras gargantas insaciables, en esta aborrecida sangre mía que aunque los fieros hados variables trastornen la araucana monarquia, ${ }^{43}$ muertos podremos ser, más no vencidos ni los ánimos libres oprimidos

(XXVI, 25, 1-6).

Parece haber sido corriente en las conquistas la destitución y eliminación de caciques. Los conquistadores, como ocurrió en México con la muerte de Moctezuma y en el Perú con la de Atahualpa, procuraban el control o el exterminio de los señores indios. No habría sido así de carecer estas persecuciones de sentido político. Las mismas eran el método más fácil para debilitar, sino disolver, las instituciones indígenas y producir el caos. Lo más importante era que agilizaba la asimilación y el pleno dominio europeo de aquellas tierras. Sin embargo, los conquistadores pronto se dieron cuenta de que la pacificación chilena era bastante diferente; tanto es así que no se logró desvanecer la rebeldía de los araucanos alzados hasta casi tres siglos de lucha. La distribución política del Arauco, segregado en pequeñas regiones cada una bajo el mando de un toqui, dificultaba que se lograra la total desorganización de la comunidad cuando sólo uno de éstos caía en cautiverio o era muerto. De esta forma aclaramos que para los militares que pisaban suelo chileno los caciques constituyeron los blancos preferidos en la guerra. Evidentemente, en esta persecución subsistía la creencia de que los nativos vivían salvajemente, carentes de orden y de normas.

Pero esto no era así para Ercilla, que percibía a los araucanos como hombres idóneos, con derecho a manejar su vida política. Para reiterar su inteligencia y sus capacidades alcanzó a llamarlos "indios con industria y artificio" (XXXIIII, 40, 6).$^{44}$ Colocolo, guerrero de mucha experiencia y años, aparece con el calificativo de sabio y prudente (XXXIIII, 38 , 3). En su "senado", Ercilla halla méritos de disciplina y policía (II, 60, 4). Al referirse a los nativos de la isla de Chiloé enaltece su organización y "leyes". Bastan estas características para sugerir que los indígenas, de acuerdo al poeta, no eran salvajes, ${ }^{45}$ puesto que se acogían a las normas de gobernar pacíficamente:

noté dellos las cosas señaladas,

los ritos, ceremonias y costumbres,

\footnotetext{
${ }^{43} \mathrm{El}$ subrayado es nuestro.

${ }^{44}$ Tampoco el Padre Acosta dejó de opinar sobre esta materia. Entiende que los indios no son rudos ni incapaces. Véase Hanke, El prejuicio racial en el nuevo mundo, 143. En el mismo libro de Hanke aparece nuevamente citado: "Que es falsa la opinión de los que tienen los indios por hombres faltos de entendimiento" (página 145, nota 66); asimismo lo reconoce el Padre José de Acosta en Historia natural y moral de Indias (Madrid: Atlas, 1954) 507-508.

${ }^{45}$ Enrique de Gandía prefiere el uso de la palabra "semiangelicales". Véase "Los fines políticos y teólogicos de La Araucana de Ercilla", El Boletín de la Academia Nacional de la Historia, 36 (Buenos Aires, 1959) 162.
} 
el trato y ejercicio que tenían

y la ley y obediencia en que vivían ${ }^{46}$ (XXXVI, 20, 1-8).

De otro lado, Ercilla insiste en las debilidades de los españoles para compararlas. Por ello se detiene a criticar la tiranía de España contra el "Estado" indígena y las libertades ciudadanas. Al dirigirse Lautaro a los suyos pinta a España como "estado infame" (IV, 37, 4). Ercilla pone esta expresión en sus labios sin vacilar. Tenía sentido literario, narrativo, pero la idea estaba dicha. Aunque Lautaro preludia estas denuncias, es Galbarino el que censura con más rigor a los conquistadores. Habla de extranjeros que con mentiras y engaños llegan a tierras araucanas fingiendo amistad para de inmediato demandar obediencia. Cuantos rechazaran someterse, estarían destinados a los castigos y a la opresión. Advierte que los cambios que impondrán los intrusos anularán su identidad colectiva:

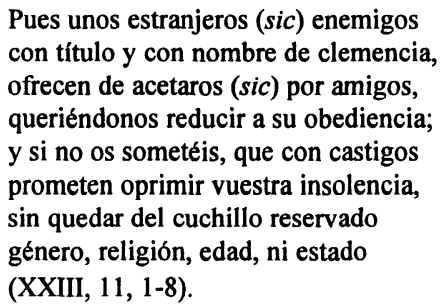

La palabra estado al pie de esta enumeración refuerza los temores de Galbarino sobre la virtual supresión de la personalidad política araucana bajo el gobierno colonial. Dentro de este contexto, comprendemos mejor la metáfora tirano cuchillo con la cual Colocolo caracteriza indirectamente a España. Aceptada la simpatía de Ercilla hacia las inquietudes de estos dos caciques, no asombran sus objeciones a la supremacía de un gobierno hacia otro por medio de violencia. Por eso permite que el "senado araucano" manifieste la validez de la voluntad libre. La coacción de ese derecho imposibilitaría la paz:

\footnotetext{
Que si la fe inviolable y juramento de vuestra parte con amor pedido y el gracioso y seguro acogimiento de nuestra voluntad libre ofrecido pueden dar en las cosas firme asiento con honra igual y lícito partido sin que los nuestros súbditos y estados vengan por tiempo a ser menoscabados,

a Carlos sin defensa y resistencia por amigo y señor le admitiremos
}

${ }^{46}$ Expresa ideas parecidas en el primer "Prólogo" de La Araucana cuando alude a la crianza y costumbres de los araucanos. Véase la edición de Morínigo, página 21. El subrayado es nuestro. 


\begin{abstract}
y el servicio indebido y obediencia de nuestra voluntad le ofreceremos; más si queréis llevarlo por violencia, ante los propios hijos comeremos y veréis con valor nuestras espadas por nuestro mismo pecho atravesadas (XVII, 10-11).
\end{abstract}

Hay evidencia de estos planteamientos en Vitoria, quien había honrado el principio de la libre determinación y las garantías a los pueblos de gobernarse conforme a sus leyes. Gómez Robledo, estudioso de algunos de los escritos del sabio teólogo, no pasa inadvertidos los celos de este pensador en cuanto al derecho de gentes. ${ }^{47}$ Recayó asimismo en Las Casas la valoración de este aspecto de su doctrina en el tratado De Regia Potestate. ${ }^{48}$ Pensaba que el monarca no podía ordenar nada que redundase en perjuicio o sacrificio de los ciudadanos sin que éstos expresaran su consentimiento. ${ }^{49} \mathrm{Al}$ mismo tiempo, planteó cuestiones inseparables de la libre determinación:

Sin el conocimiento expreso de los ciudadanos directamenta-mente afectados, no puede imponer el sacrificio de una ciudad o territorio para el bienestar de todo el reino ni puede sacrificar un reino contra la voluntad de sus ciudadanos para socorrer a otro reino de la comunidad de pueblos, que gobierna un mismo rey (CXXIX-CXXX) ${ }^{50}$

Estos corolarios revelan la visión que a la larga engendró el derecho internacional, aunque sorprendían en la época.

\title{
RELIGIÓN Y CONQUISTA
}

Durante el siglo XVI la misión de cristianizar a los indios supuestamente guió los planes de los conquistadores. Para Vitoria y Las Casas la declaración de guerra a los indígenas reacios al bautismo, como la proclamaban Palacios Rubios y Sepúlveda, contrastaba con las tareas de conquistar y pacificar. Según Vitoria, era ilícito forzar a los aborígenes a reverenciar al Dios cristiano. Lo recomendable sería el respeto al carácter natural de la fe. Importaba también que los indios decidieran libremente qué religión seguir luego de que se les impartiera algún tipo de educación religiosa. Alude a pueblos ideológicamente opuestos con miras a defender sus reclamos para los americanos. Su argumento es contundente: “... porque si suponemos que los sarracenos al mismo tiempo

\footnotetext{
${ }^{47}$ Antonio Gómez Robledo, Política de Vitoria (México: Imprenta Universitaria, 1940) 137. Vitoria comenta que ... "non licet uni regno nolle teneri iure gentium". Traducción espanfola: “... no es legal para un gobierno el no contar con el derecho de gente" (Ibid., 140).

${ }^{48}$ Bartolomé de Las Casas, De Regia Potestate o derecho de autodeterminación (Madrid: Consejo Superior de Investigación Científica, 1969) CXXIX.

${ }^{49}$ Ibid.

${ }^{50}$ Para una revisión de estas ideas, consúltese Lewis Hanke, Bartolomé de Las Casas. Pensador, político, antropólogo (Buenos Aires: Editorial Universitaria de Buenos Aires, 1968).
} 
que los cristianos, propusieran simplemente su secta a los bárbaros, es cierto que no estarían obligados a creer a aquéllos; luego tampoco a los cristianos que propongan a la fe sin algunas razones y motivos persuasorios. Porque no pueden, ni están obligados a adivinar qué religión es más verdadera, si no se presentan motivos más probables por una de las dos partes ...." ${ }^{51}$ Vitoria también precisa que los nativos podían estar exentos de la doctrina cristiana y alcanzar su salvación espiritual. ${ }^{52}$ Hace hincapié en la ilegitimidad de perjudicar a los aborígenes que hayan rechazado la fe cristiana. Si predicada la religión "no la abrazan, no es razón suficiente para que los españoles puedan hacerles la guerra, ni obrar contra ellos por derecho de guerra". ${ }^{53}$ Insiste sobre este punto: "Aunque la fe haya sido anunciada a los bárbaros de un modo probable y suficiente, y éstos no la hayan querido recibir, no es lícito, sin embargo, por esta razón, hacerles la guerra ni despojarlos de sus bienes". ${ }^{54}$ Estaba claro que las afinidades religiosas eran decisiones voluntarias. En este sentido el "llegarse a los misterios y Sacramentos de Cristo sólo por temor servil es sacrilegio". 55 Incluimos uno de los trozos más expresivos de la relección de Vitoria:

Además, la guerra no es argumento en favor de la verdad de la fe cristiana; luego por la guerra los bárbaros no pueden ser movidos a creer, sino a fingir que creen y que abrazan la fe cristiana, lo cual es abominable y sacrílego. Y aunque Escoto (4. Sent., dist. 4, q. última) dice que obrarían religiosamente los príncipes que obligaran a los infieles a recibir la fe por la amenaza y el terror, sin embargo, parece que esto no se entiende sino de los infieles, que por otra parte son súbditos de los príncipes cristianos ..., por lo que pienso que ni Escoto mismo afirmaría tal cosa de estos bárbaros. Es claro, pues, que tampoco este título es suficiente y legítimo para ocupar las provincias de los bárbaros. ${ }^{56}$

Las Casas consideraba que no debía castigarse a los hombres que desconocieran la existencia de Dios. ${ }^{57}$ Se opuso a que los conquistadores se escudaran en su misión evangélica para guerrear contra los naturales. A causa de estos abusos no reprende a los indios por la muerte de algunos sacerdotes; prácticamente, esta violencia quedaba justificada a modo de venganza. ${ }^{58}$ Concordamos en que la religión servía a los conquistadores de "pretexto para arrebatar a otros el poder que tienen y subyugar provincias extrañas". ${ }^{9}$ Para diferenciar

\footnotetext{
${ }^{51}$ Vitoria, 208-209.

${ }^{52}$ Loc. cit.

${ }^{53}$ Loc. cit.

${ }^{54}$ Vitoria, 211.

${ }^{55}$ Loc. cit.

${ }^{56}$ Vitoria, 212.

${ }^{57}$ Las Casas, 1975, 146.

${ }^{58}$ Lo expone Las Casas con fines de lograr calmar las críticas que producían estos actos: "mataron a algunos predicadores no por el hecho de ser predicadores, sino porque tanto aquéllos como todos sus territorios de las Indias fueron objeto por parte de los españoles de toda clase de malos tratos ..." (Ibid., 234). Para proteger a estos misioneros Las Casas recomienda la construcción de una ciudadela defendida por guardias buenos y probados. Señala Angel Losada que sobre este aspecto el dominico no excluye la utilización de "cierta fuerza armada muy bien pagada para defensa exclusivamente de los predicadores". Esto es un elemento esencial en la doctrina del eclesiástico, coincidente en muchos aspectos con la de Sepúlveda, por raro que parezca (Ibid., 241).

${ }^{59}$ Loc. cit.
} 
los procedimientos empleados en la asimilación cristiana de los indios, Las Casas recurre a sus experiencias como misionero. La deslealtad de aquéllos podría apaciguarse si los españoles imitaban los métodos de evangelización pacífica que él aplicó en Vera Paz cuando fue obispo de esa región. ${ }^{60}$

Estos asuntos religiosos eran mucho más complejos. Fray Gil en una carta al Consejo de Indias ${ }^{61}$ había acusado a los conquistadores de predicar unos preceptos bíblicos que ellos luego no cumplían por su manera de conquistar. Cegados por el oro y los títulos, la religión contenía las excusas permisibles para los enfrentamientos contra los naturales. Esta rapacidad sirve de base al fraile para condenar la hipocresía y las faltas españolas; igual la conquista. En contraste con Vitoria, quien hasta donde sabemos no abordó el problema, Las Casas repugnó esta actuación. Sus escritos son harto conocidos. ${ }^{62}$

Ercilla, además de sus propias experiencias, incorpora en sus reproches a los conquistadores los argumentos de Las Casas y Fray Gil. A través de Galbarino denuncia el papel falso que jugaba la religión en el sometimiento de los indios:

Y es un color, es apariencia vana

querer mostrar que el principal intento

fue el extender la religión cristiana

siendo el puro interés su fundamento;

\footnotetext{
${ }^{60}$ Las Casas resume los procedimientos aplicados en la región: "Envíense, de las regiones ya aplacadas y en las que algunos ya han abrazado nuestra fe, legados de entre aquellos recientemente convertidos, para que actúen en nombre de algunos piadosos y religiosos varones, a los cuales ellos ya son adictos; envíense, digo, estos legados a anunciar a las demás gentes de su provincia cómo aquellos piadosos predicadores, totalmente alejados de las costumbres de los demás sicarios, va a aquellas provincias precisamente a anunciarles el camino de la verdad y el culto al verdadero Dios. De este modo yo he logrado atraer a la fe extensísimas provincias" (loc. cit.). Mucho se ha escrito sobre esta cruzada de Las Casas en torno a crear modelos para adoctrinar a los nativos sin el uso de las armas. Vera Paz fue una empresa ideal que interesa porque de haberse logrado hubiera podido ayudar a la asimilación de los indígenas de manera pacífica y falta de medidas graves. Lo que se conoce como Vera Paz es la provincia de Tuzulutlán, o tierra de guerra en Guatemala. Véase Marcel Bataillon, "La Vera Paz, novela e historia", Estudios sobre Bartolomé de Las Casas, 181-243. Lo que resulta curioso de este estudio, entre otras muchísimas cosas, es la casi total revaluación de lo que cuenta Fray Antonio de Remesal sobre Vera Paz, mayormente sus inexactitudes. Véase Remesal, Historia general de las Indias occidentales y particular de la gobernación de Chiapa y Guatemala en Biblioteca de Autores Españoles (Madrid: Ediciones Atlas, 1964). Bataillon ofrece otro título, pero sabemos que se trata de la misma obra: Historia de la provincia de San Vicente de Chyapa y Guatemala de la Orden de Padre Sancto Domingo (Madrid: n. e., 1619). Otro trabajo sobre Las Casas, también muy documentado, según las palabras de Bataillon, es la respetada tesis de André Saint-Lu, La Vera Paz, esprit évangé et colonisation (París: Centre de Recherches Hispaniques, 1968). De Angel Losada, Fray Bartolomé de Las Casas a la luz de la moderna crítica histórica (Madrid: Editorial Tecnos, 1970).

${ }^{61}$ Fray Gil González de San Nicolás, “Carta al Presidente y Oidores del Consejo de Indias”, Colección de documentos inéditos para la historia de Chile, preparados por José Toribio Medina, XVII (Santiago de Chile: Imprenta Elzeviriana, 1901) 276-283.
}

${ }^{62}$ Véase nota 60. 
su pretensión de la codicia mana, que todo lo demás es fingimiento pues los vemos que son más que otras gentes adúlteros, ladrones, insolentes (XXIII, 13, 1-8).

Se entiende que Ercilla reprobaba el empleo de las armas con fines evangélicos. Su uso causaba que la guerra perdiera su motivación pacifista, mientras creaba otros inconvenientes:

y los cristianos príncipes no deben

favorecer jamás ni dar licencia a condenadas armas que se mueven por odio, por venganza o competencia; (XXXVII, 10, 1-4)

Al fijarnos en la distribución de estos versos sobresale la estructura en la cual están vertidas las censuras del poeta. Las mismas ocupan diversos niveles. La religión (cristianismo) constituye el primer plano. Le siguen los príncipes (poder real, o posiblemente España). La defensa de estos valores conduce a las armas (o la guerra colonial). De esta explicación deducimos que la palabra condenadas es adjetivo y participio con sentido reprobatorio.

\section{Maltrato a LOS INDios}

No estaba asegurada la conquista de toda América cuando los conquistadores recurrieron al empleo de indios para sus servicios. Se beneficiaron mayormente de ellos en las labores mineras, servicios personales, transportación de cargas y encomiendas. Pese a la existencia de estatutos reguladores, éstos nunca llegaron a obedecerse. ${ }^{63}$ Por la sed de riquezas, los españoles redujeron a los indios a una servidumbre semejante a la esclavitud. Las Casas condenó estas demandas económicas por rudas y achacaría al problema las continuas mermas de población aborigen. Como prueba basta una descripción bastante

\footnotetext{
${ }^{63}$ Sobre este problema de las encomiendas y otros, véase Amunátegui Solar, Las encomiendas indigenas en Chile, II, (ya citado); Leslie Byrd Simpson, The Encomienda in New Spain; Forced Native Labor in the Spanish Colonies, 1492-1550 (Berkeley: University of California Press, 1929); Silvio Zavala, El servicio personal de los indios en el Perú (México: El Colegio de México, 19781980), también De encomiendas y propiedad territorial en algunas regiones de la América española (México: Antigua Librería Robledo, 1940) y su más reciente estudio: El trabajo indígena en los libros del virrey Luis de Velasco 1550-1552 (México: Centro de Estudios Históricos del Movimiento Obrero Mexicano,1981); Robert G. Keith, Conquest and Agrarian Change: the Emergence of the Hacienda System on the Peruvian Coast (Cambridge, Massachussetts: Harvard University Press, 1976), Salvador Rodríguez Becerra, Encomienda y conquista: inicios de la colonización en Guatemala (Sevilla: Universidad de Sevilla, 1977); Jorge Chapa, The Political Economy of Labor Relations in the Silver Mines of Colonial Mexico (Berkeley: Institute for the Study of Social Change, 1978); Nadia Carnero Albarrán, Minas e indios del Perú (Lima: Dirección Universitaria de Proyección Social de San Marcos, 1981).
} 
cruda que este cronista ofrece en Brevísima relación para apreciar cómo los indios cargadores (o aquéllos que desempeñaban el trabajo de acémilas) eran encadenados por el cuello, obligados a transportar enormes pesos hasta rendirse extenuados de fatiga. Estos maltratos en detrimento de los americanos ocurrían a diario en todas las Indias: ${ }^{64}$

Hallaron grandes poblaciones de gentes muy bien dispuestas, cuerdas, políticas y bien ordenadas. Hacían en ellos grandes matanzas (como suelen) para entrañar su miedo en los corazones de aquellas gentes. Afligíanlos y matábanlos con echalles cargas como a bestias. Cuando alguno cansaba o desmayaba, por no desensartar de la cadena donde los llevaban en colloras otros que estaban antes de aquél, cortábanle la cabeza por el pescuezo e caía el cuerpo a una parte y la cabeza a otra ...65

Conviene observar que Fray Gil detestó esta conducta en Chile. En un carta enviada a Las Casas examina los abusos con los cuales los españoles acosaban a los araucanos. ${ }^{66}$ Sus críticas dan la impresión de estar leyendo al obispo de Chiapas:

El que tiene encomendados en Chile, se sirve de servicio personal de todos los de su repartimiento, chicos y grandes, continuamente, muy peor que los esclavos, porque vienen á servir de veinte y treinta leguas, y traen lo que han de comer á cuestas, sin otras cargas que por el provecho de sus amos traen y llevan siempre de una parte á otra. Ningún indio es señor de su mujer, hijos ni hijas, porque á los indios ocupan en hacer sementeras y casas y guarda de ganado, y á las indias en hilar y tejer en los beneficios de las chacarras, y en todo lo demás que sus encomendados han menester, y tráenlos en estos servicios á los unos y á a los otros desde nifios, de suerte que ninguno huelga desde que nace hasta que muere; no consienten á las indias hilanderas que se casen, porque dicen que se ocuparán en servir á sus maridos y no hilarán tanto, y á esta causa las tienen encerradas de noche, y en algunas partes de noche y de día para que hagan las telas más delgadas. Y, finalmente, son tantos los agravios que padecen, que si no es viéndolo, no se pueden relatar sin sentir ... $^{67}$

Vale esta correspondencia para constatar los contactos ideológicos de Ercilla con Las Casas y Fray Gil, pues en La Araucana trata, aunque muy sumariamente, estos temas. El poeta delega sus censuras en Galbarino. ${ }^{68}$ Vemos al cacique divulgando las deficiencias

${ }^{64}$ También este problema lo destaca Pedro de Ona, véase mi artículo "Principios indigenistas de Pedro de Ona presentes en Arauco domado", Quaderni Ibero-Americani, 73 (Torino, 1993), en prensa y mi trabajo publicado en Cuadernos Americanos citado en nota 71.

${ }^{65}$ Bartolomé de Las Casas, Brevísima relación de la destruición (sic) de las Indias, en Tratados, prólogos de Lewis Hanke y Manuel Giménez Fernández (México: Fondo de Cultura Económica, 1974) 155. En la misma crónica ya había condenado estos transportes de cargas al escribir sobre los indios de la provincia de Santa Marta. Véase páginas 121-122.

${ }^{66}$ Fray Gil González de San Nicolás, "Relación de los agravios que los indios de las provincias padecen", Colección de historiadores de Chile y documentos relativos a la historia nacional, XXIX (Santiago de Chile: Imprenta del Ferrocarril, 1861-1923) 461-466.

${ }^{67}$ Ibid., 463.

${ }^{68}$ Ya en otro trabajo nuestro (véase nota 76) mencionamos que Galbarino es portavoz de la ideología crítica de Ercilla. Me informa el profesor José Durand que Cedomil Goiç abordó en una conferencia ofrecida en la Universidad de Notre Dame (Indiana) la importancia ideológica de este personaje en La Araucana. Mis observaciones son independientes. 
de la administración colonial al lamentarse de que los araucanos eran forzados al transporte de cargas a lugares apartados. A esto agregamos que no exagera al afirmar que de asentarse los españoles en Chile de forma permanente, los habitantes del Arauco se confundirían con las brutas bestias. Sabemos que el número de víctimas debido a las labores asignadas a los indios era cuantioso. En consecuencia, Ercilla no perdona estos agravios; y de ahí parte para sostener que "el fin de los trabajos es la muerte" (XXVI, 36, 7). Por esto detesta lo abusivo del transporte de sacos:

Cuál por aquella parte, cuál por ésta, cargado de fardel o saco guía; cuál por lo más espeso de la cuesta arrastrando el ganado se metía. Cuál con hambre y codicia deshonesta ${ }^{69}$ por sólo llevar más se detenía, costando a más de diez allí la vida la carga y la codicia desmedida (XXVIII, 69, 1-8).

Con todo, las cargas componían una minúscula porción del problema. Había otros trabajos, y aunque Ercilla no especifica cuáles, no hay riesgos en suponer que éstos debían ser agotadores. Esto salta a la vista al calificar la servidumbre de dura y el yugo de eterno, según les han sido impuestos a los araucanos (XVI, 68, 8). Si este problema había estado vigente anteriormente bajo el gobierno de Pedro de Valdivia, es con el de García Hurtado de Mendoza que la situación empeora. Remitámonos a unas líneas en las que este gobernante comunica a Millalauco, mensajero despachado por el "senado araucano", que si estos indígenas aceptaban como buenas y legítimas la amistad y la doctrina de los españoles, se les relevaría, a nombre del rey, de muchos trabajos (XVII, 14, 8). En otro episodio, cuando el indígena Pran le habla al yanacona Andresillo, deplora las nuevas obligaciones de sus compañeros. El calificativo "vergonzosa" es una desaprobación de esta conducta. Estas acusaciones le son útiles a Ercilla para recalcar la dura servidumbre sobre la cual nos advirtió en otro canto:

Mira, pues, lo que desto te parece, conoce el tiempo y la ocasión dichosa, no seas ingrato al cielo que te ofrece por sólo que la acetes tan gran cosa;

\footnotetext{
${ }^{69}$ Fernando de Santillán, compañero de Ercilla y oidor de Lima que se trasladó a Chile en la embarcación de García Hurtado de Mendoza, escribió sobre este problema de las cargas. Comparó el dolor de los indios a causa de estas labores con el de las bestias: "y luego mandé publicar y ejecutar la dicha provisión de S. M. sobre las cargas, porque una de las principales granjerías que los encomenderos allá tenían era traer recuas de indios cargados con mercancías e otras cosas de sus granjerías, desde la dicha ciudad al puerto de Valparaíso, que son quince leguas de muy mal camino, y otras partes, llevándose los encomenderos el jornal que por lo susodicho ganaban los dichos indios, de lo cual andaban muy acosados y con mataduras en las espaldas, como bestias, y otros morían en el trato". Véase Alvaro Jara, Fuentes para la historia del trabajo en el Reino de Chile, I (Santiago de Chile: Centro de Investigaciones de Historia Americana, 1965) 16.
} 
da la mano a tu patria que perece en dura servidumbre vergonzosa, y pide aquello que pedir se puede, que todo desde aquí se te concede ${ }^{70}(\mathrm{XXX}, 58,1-8)$

Casi al final de La Araucana, Ercilla incluye una apreciación muy personal de la conquista de Chile. Conoce las injusticias de los españoles en la región, la poca piedad en los combates ${ }^{71}$ y la opresión que padecían los indígenas. ${ }^{72}$ Por eso, el poeta reacciona, no

${ }^{70}$ Un trabajo de Diego de Erazo, conquistador contemporáneo de Ercilla, atestigua lo dura que era la vida de los araucanos. En sus recriminaciones, el problema de las cargas está presente: "Dado caso que después de buena gana se hubiesen sujetado y reconocido á S. M., pagándole tributos, nó pudieron permanecer en esta sujecion por los muchos agravios que los españoles les hacían sin tasa ni concierto, ni acordarse de enseñarles la doctrina cristiana. Y habiendo experimentado que estos trabajos y agravios les venían por haberse sujetado de su voluntad y que no había quien los defendiese, y los que los habían de amparar y aliviar los cargaban y trabajaban, les pareció ser justo y forzoso rebelarse y negar la obediencia al rey y sus ministros, pues con la voluntad libre que se la dieron, con esa se la pudieron quitar habiendo tan justas causas como lo eran los agravios que les hacían sin tener otra defensa mas de la de sus lanzas. Aunque sea verdad que despues de la primera rebelion y daños tornaron á dar segunda y diversas veces la paz y obediencia, nunca hallaron dispusicion (sic) en los españoles para conservarla, sin mudanza en su cudicia (sic) y malos tratamientos, quitándoles servicio personal del tercio del pueblo para sacar oro, y los hijos y hijas para sus casas, y que esto quedaba tan entablado que los gobernadores no miraban á lo que estaba bien á los indios sino sólo á los españoles; y á los trabajaban en las minas no se les pagaban por jornal, mas que solo el sesmo de lo que sacaban á cabo del año; y á sus hijas se las tenía sirviendo toda la vida y no con buen ejemplo della. Véase Domingo de Eraso, "Papel sobre la esclavitud de los indios de Chile", Colección de documentos inéditos para la historia de España, L (Madrid: Imprenta de la viuda de Calero, 1867) 224-225.

${ }^{7}$ Sobre este tema, véase mi trabajo "Las guerras en Chile y la despoblación araucana. Reacción de Ercilla y otros cronistas”, Cuadernos Americanos, II/20 (México: Nueva Época, marzo-abril, 1990) 185-204 y también mi libro Las ideas de la guerra justa en Ercilla y en La Araucana (Santiago, Chile: Universidad de Chile, 1992).

${ }^{72}$ Para otras fuentes de información sobre la conquista y la opresión de los indios véase, además de las notas 60 y 68-69, a Guillermo Céspedes del Castillo, "La sociedad colonial americana en los siglos XVI y XVII", en Vicéns-Vives, Historia de España y América, III (Barcelona: Editorial Vicéns-Vives, 1961) 388-588. Alvaro Jara, Problemas y métodos de la historia económica hispanoamericana (Caracas: Universidad Central de Venezuela, 1969). También del mismo autor Guerra y sociedad en Chile: la transformación de la guerra de Arauco y la esclavitud de los indios (Santiago de Chile: Editorial Universitaria, 1971). Silvio Zavala, Las instituciones jurídicas en la conquista de América (Madrid: Centro de Estudios Históricos, 1935); asimismo La encomienda indiana (Madrid: Centro de Estudios Históricos, 1935). Domingo Amunátegui Solar, Las encomiendas indijenas en Chile; Eugene Korth, 1968 (ambos citados anteriormente). José Durand, "El chapetón Ercilla y la honra araucana", Filologia, X (Buenos Aires, 1964) 113-134; Ramón Menéndez Pidal, “¿Codicia insaciable? ¿Ilustres hazañas?”, Escorial, I (Madrid, 1940) 21-35. Pérez Bustamante, "El lascasismo en La Araucana", Revista de Estudios Políticos, 64 (Madrid, 1952) 157-168. Paulino Castañeda Delgado, "La condición miserable del indio", Anuario de Estudios Americanos, XXVIII (Sevilla, 1971) 245-335. 
en favor de los soldados ni de España, sino de los americanos, de la justicia y de la libertad. $\mathrm{Su}$ descontento se expresa claramente en la siguiente estrofa:

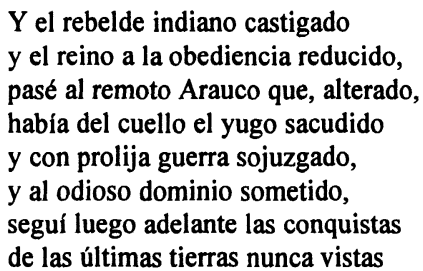

(XXXVII, 68, 1-8).

Podemos citar otros ejemplos, pero sólo hemos querido resumir las similitudes más obvias entre Ercilla y Vitoria y Las Casas. No hay duda de que las preocupaciones de estos dominicos se difundieron con mucho celo entre los defensores de los indios que arribaban a las Indias. En cuanto a Vitoria, tenemos de muestra a Fray Gil González de San Nicolás. Aunque quizá las relaciones de este último con el obispo de Chiapas fueron menos calurosas que las que sostuvo con su maestro Vitoria, no puede negarse que todos concurren en remedios semejantes para corregir las fallas del sistema colonial y el modo de culminar la pacificación de los nativos. Si nos atenemos a las noticias que trajo consigo Fray Gil a América, hay que dar por sentado que algo aprendió Ercilla de él mientras ambos vivían en Chile y se embarcaron juntos en su viaje de retorno a Lima.

Si bien las conversaciones de estos dos españoles jugaron un papel decisivo, admitimos que los problemas que Fray Gil planteó eran asimismo debatidos en Chile por otros españoles. Sobre esto, vale citar el caso del licenciado Fernando de Santillán. ${ }^{73}$ También se debe tomar en cuenta que Ercilla era hijo de un jurista-autor que escribió sobre la guerra justa, ${ }^{74}$ y que el autor de La Araucana estudió en Valladolid ${ }^{75}$ y residió en Lima antes y

\footnotetext{
${ }^{73}$ Santillán, "Relación de lo que el licenciado Fernando de Santillán, oidor de la Audiencia de Lima, proveyó para el buen gobierno pacificación y defensa del reino de Chile", Colección de documentos inéditos para la historia de Chile, XXVIII (Santiago de Chile: Imprenta Elzeviriana, 1901) 284302.

${ }^{74}$ Dato suministrado por el profesor José Durand. El padre del poeta fue Fortún García de Ercilla. José Toribio Medina destaca que Carlos V le guardó muchas consideraciones. Según Medina "su nombre corría en alas de la voladora fama como autor de obras de su profesión estimadísimas", Vida de Ercilla, 10.

${ }^{75}$ En Valladolid tuvo de maestro a Juan Cristóbal Calvete de la Estrella, encargado de la educación de los pajes de Felipe II, autor, según González de Barcia, de una crónica perdida acerca de Chile titulada Historia de Chile. Fue también autor de otra sobre el Perú titulada Rebelión de Pizarro en el Perú y vida de don Pedro de Gasca (Madrid: Impresión y Fundición de M. Tello, 1889). Sobre este cronista véase a José Toribio Medina "El preceptor de Ercilla", Boletín de la Academia Chilena, II, VII (Santiago, 1919) 265-286. La información que ofrece González de Barcia la recoge Medina en la página 267. Como nota aparte, Valladolid tiene importancia por haber sido en esa ciudad donde se suscitaron las polémicas entre Bartolomé de Las Casas y Sepúlveda. El convento de San Gregorio en el cual Las Casas residía quedaba cerca de la residencia de Felipe II. Algunos rumores de estas controversias se habrían de escuchar por los pasillos reales mientras Ercilla acompañaba al Príncipe.
} 
después de viajar a Chile. ${ }^{76}$ Había en Perú una fuerte corriente en pro de los indígenas, pues las ideas de Vitoria y de Las Casas se conocían y se debatían casi desde el comienzo de la conquista y en tiempos de los Hurtado de Mendoza. ${ }^{77}$ A esto se añade que en España se tenían noticias de algunas obras de Las Casas antes de que Ercilla concluyese la redacción de La Araucana. ${ }^{78}$

${ }^{76}$ Obtendría licencia de Felipe II para viajar al Perú el 5 de marzo de 1555. Véase José Toribio Medina, Vida de Ercilla, 25, también página 27, nota 55. Parte de Cádiz a principios de diciembre del mismo año. Luego de algún tiempo en Panamá con el recién nombrado virrey Hurtado de Mendoza llega a Lima el 29 de junio de 1556. Saldría para Chile el 2 de febrero de 1557. Regresó a Lima posiblemente durante los últimos días de febrero de 1559 (José Toribio Medina, Vida de Ercilla, 96). Y se marcharía de la ciudad virreinal con rumbo a Panamá probablemente en septiembre de 1561.

${ }^{77}$ Fray José María Vargas, La conquista espiritual del imperio de los incas (Quito: "La Prensa Católica", 1948); también Fray Domingo de Santo Tomás: defensor y apóstol de los indios del Perú (Quito: Editorial "Santo Domingo", 1937). Marianne Mahn-Lot, "Transculturation et Evangélisation dans le Pérou de XVIue siecle. Notes sur Domingo de Santo Tomas, disciple de Las Casas", Méthodologie de l'histoire et des sciences humaines (Toulouse: Privat, Editeur, 1957) 353-365. Guillermo Lohmann Villena, "El Licenciado Falcón (1521-1587) Vida, escritos y actuación en el Perú de un procurador de los indios", Anuario de Estudios Americanos, XXVII (Sevilla, 1970) 131184. Del mismo autor "Notas sobre la estela de la influencia lascasiana en el Perú. El Licenciado Falcón y las corrientes criticistas", Anuario de Historia del Derecho Español (Madrid, 1971) 373 423. También de Lohmann Villena "La restitución por conquistadores y encomenderos: un aspecto de la incidencia lascasiana en el Perú", Estudios lascasianos IV Centenario de la muerte de Fray Bartolomé de Las Casas (1566-1966) (Sevilla: Escuela de Estudios Hispano-Americanos de Sevilla, 1966) 21-89. Lisson Chaves, La iglesia de España en el Perú, I/1 (Sevilla, 1943). Vargas Ugarte, Pareceres jurídicos en asuntos de Indias (Lima: n. e., 1951). Roberto Levillier, Organización de la iglesia y órdenes en el virreinato del Perú en el siglo XVI (Madrid: Sucesores de Rivadeneyra, 1919). "Parecer de D. Fr. Matías de San Martín, obispo de Chiapas sobre si son bien ganados los bienes adquiridos por los pobladores y encomenderos de Indias", Colección de documentos inéditos de América y Oceanía, VII (Madrid: Frías y Companía, 1867).

${ }^{78}$ Más aún, tenemos en nuestro poder, un manuscrito de Fray Gil González de San Nicolás dirigido al Padre Las Casas desde Chile en 1561. De seguro, González de San Nicolás le habló a Ercilla sobre los trabajos del polémico cronista y su lucha por los derechos de los amerindios. Véase también nota 66 . 
